

International Journal of Emerging Technology and Advanced Engineering

Website: www.ijetae.com (E-ISSN 2250-2459, Scopus Indexed, ISO 9001:2008 Certified Journal, Volume 12, Issue 02, February 2022)

Manuscript Received: 02 January 2022, Received in Revised form: 01 February 2022, Accepted: 05 February 2022

DOI: 10.46338/ijetae0222_13

\title{
Mobile Application to Reduce Illiteracy in Rural Areas of Peru
}

\author{
Meyluz Monica Paico-Campos ${ }^{1}$, Enrique Lee Huamaní ${ }^{2}$, Alexi Delgado ${ }^{3}$ \\ ${ }^{1}$ Systems engineer program, Universidad de Ciencias y Humanidades, Lima-Perú \\ ${ }^{2}$ Image Processing Research Laboratory, Universidad de Ciencias y Humanidades, Lima Perú \\ ${ }^{3}$ Mining Engineering Section, Pontificia Universidad Católica del Perú, Lima-Perú
}

\begin{abstract}
Illiteracy is one of the main problems that Peru faces in education, it is known that the highest percentage of illiteracy occurs in rural areas of our Country. That is why the research work is focused on children and adults who cannot read or write. Therefore, a mobile application prototype was designed to reduce illiteracy in Peru where they can learn to read and write with the activities provided in the application. A hybrid methodology was used, which is the union of Design Thinking and soft systems and the Moqups tool, since they were the most appropriate to develop this work. In this way, the result was the design of a mobile application that will make children and adults who do not know how to read or write to learn with the appropriate educational methods, such as the alphabetical method and the syllabic method, which will make their learning easy. and simple. Likewise, you can take advantage of the use of technology to improve and strengthen education, since educational technology is a didactic and innovative tool that can be implemented in educational classrooms.
\end{abstract}

Keywords - Mobile application, hybrid methodology, educational methods, illiteracy, educational technology.

\section{INTRODUCTION}

One of the main problems facing education in Peru is illiteracy. According to data from the Ministry of Education (MINEDU), the illiteracy rate in Peru is $5.91 \%$, that is, more than $1,300,000$ people who cannot read or write [1].

On the other hand, according to the results of the Program for the International Evaluation of Students (PISA) carried out in 2018, our country is in position 64 occupying one of the last positions in quality of the educational system [2].

It is known that since 2011, June 13 is commemorated the Day of Peru free of Illiteracy, 10 years have passed and there are still people who do not have their primary right, which is education. In the same way, we know that the large part of that percentage who cannot read or write are women from rural areas. Currently it is known that illiterate people do not have a formal job, which prevents them from having an established salary and with the benefits established by law [3].
It is important to note that technology over the years has been improving and it turns out to be very helpful in our daily lives, observing this problem that our country has with education, it has been observed that as a learning methodology the use of Technologies of information and communication (ICT) turns out to be more interactive and keep the attention of students more easily [4].

Likewise, the results obtained on the use of a mobile application in teaching reading showed that ICTs develop skills and motivate students' learning, that is, they learned by playing [5].

On the other hand, integrating technological tools in education is to make educational processes in different areas more dynamic, making teaching innovative. In the results obtained from the research work on the use of technology in literacy learning, a high impact on learning was found, since it turned out to be a satisfactory and very easy-to-use tool [6].

In the same way, it has been shown that the use of mobile applications to improve learning in special education has been of great help, since children with Attention Deficit Hyperactivity Disorder (ADHD), dyslexia, dysgraphia and dyspraxia can learn in a more fun way and achieve a positive experience in them, capturing their concentration to the maximum [7]. It should be noted that for a child to feel motivated to continue learning it is by showing them motivating messages and congratulating them on their achievements.

The importance of this work is to find a technological solution so that children and adults in rural areas of Peru can learn to read and write through a mobile application that will be based on the appropriate teaching methods for their learning.

The objective of the work is to design a mobile application for children and adults to learn to read and write through technological tools and without the supervision of a teacher. As a result, when using the mobile application, they can learn to read and write with the different teaching methods such as: Alphabetic, phonetic and syllabic method, which will give us as a result that they can learn in an easy way. 


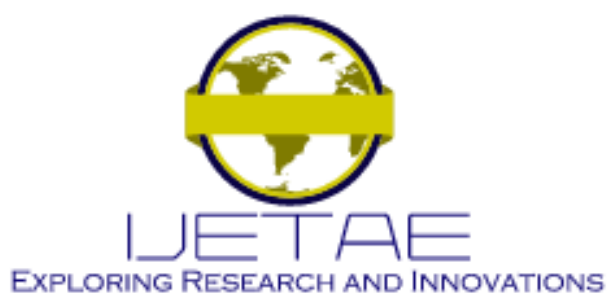

International Journal of Emerging Technology and Advanced Engineering

Website: www.ijetae.com (E-ISSN 2250-2459, Scopus Indexed, ISO 9001:2008 Certified Journal, Volume 12, Issue 02, February 2022)

This work is structured as follows, in section number II the methodology used for educational software will be described in detail, section III presents the results obtained and finally, section IV the conclusions.

\section{MEthodology}

In this article, the alphabetical method, syllabic method and a hybrid methodology that is the union of Design Thinking and soft systems were used. The first two stages of the soft systems methodology and the next three of the Desing Thinking methodology were taken into consideration.

\section{A. Alphabetical method}

The alphabetical method is also called spelling, since it consists of learning the shape of the letters, where children must become familiar with the letters. In this way, it turns out to be a simple method, since it allows the organization of words from the simplest to the most complex [8].

\section{B. Syllabic method}

The syllabic method consists of pronouncing words syllabically, emitting combinations of two or more sounds. That is why the syllabic method manages to teach students to read in a simple way, since first the children will become familiar with the letters and their sounds [9].

\section{Unstructured situation}

In this stage, the causes of the problem will be obtained by making a definition through a survey that will be provided to a group of parents. A form was developed to a group of 30 parents where the following questions were asked:

- For you, what do you think is the main cause of illiteracy in our country?

- What would be the main consequence of illiteracy?

- For you, what would be the maximum age to learn to read and write?

- Do you think that you can learn to read and write through a mobile application?

- What should the mobile application have to achieve with the objective (learn to read and write)

- How should the mobile application be structured?

\section{Structured situation}

At this stage, all those involved are identified as materials, entities, infrastructure involved in the research work.
For the development of the research, those involved are children and adults who cannot read, the ministry of education, the government and all this will be represented in a pictorial table as shown in Fig. 1. Through this pictorial table it is observed that the mobile application is based on children and adults who cannot read or write in this way, the support of the Ministry of Education and the Government of Peru is sought.

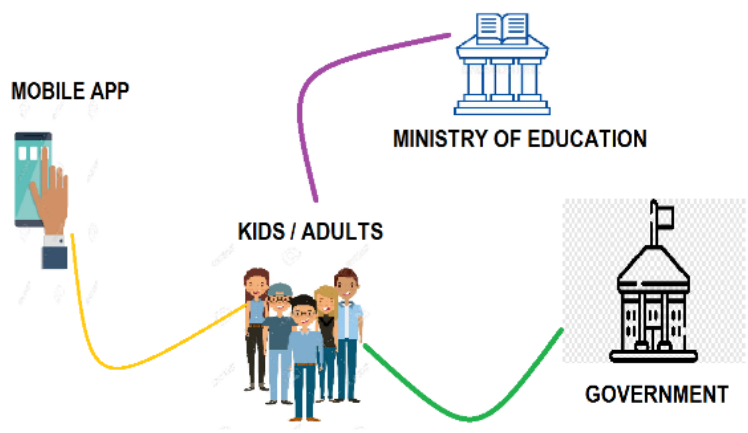

Fig.1 Stakeholder Structure

\section{E. Mobile app functionality}

In Fig. 2 the physical architecture of the mobile application is observed, which indicates that so that users can access the mobile application they will have to download it from the play store, which they achieve by advancing each activity is stored through the device, that each Once they open the application they will be able to see how they have been improving since they started using it. In the same way, Fig. 3 shows the flow diagram of how the application works.

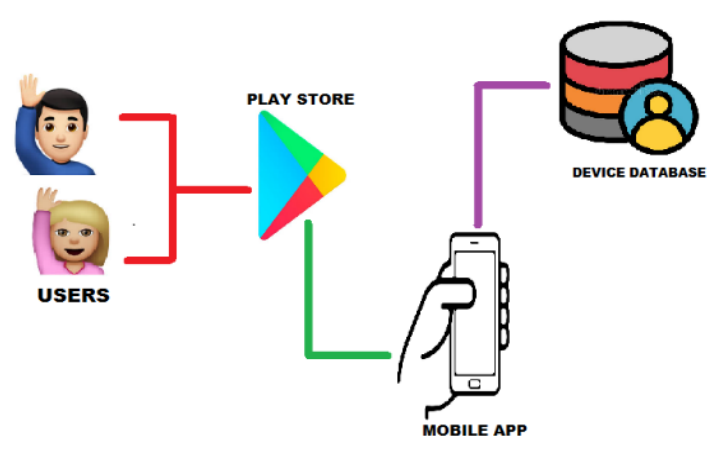

Fig,2 Physical architecture 


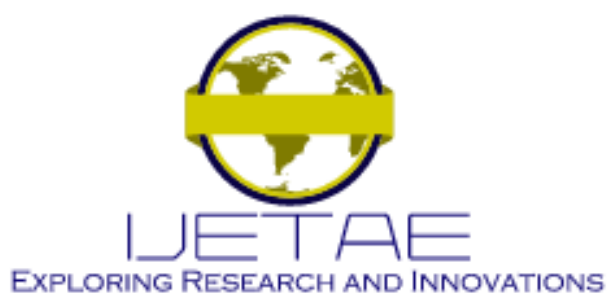

International Journal of Emerging Technology and Advanced Engineering Website: www.ijetae.com (E-ISSN 2250-2459, Scopus Indexed, ISO 9001:2008 Certified Journal, Volume 12, Issue 02, February 2022)

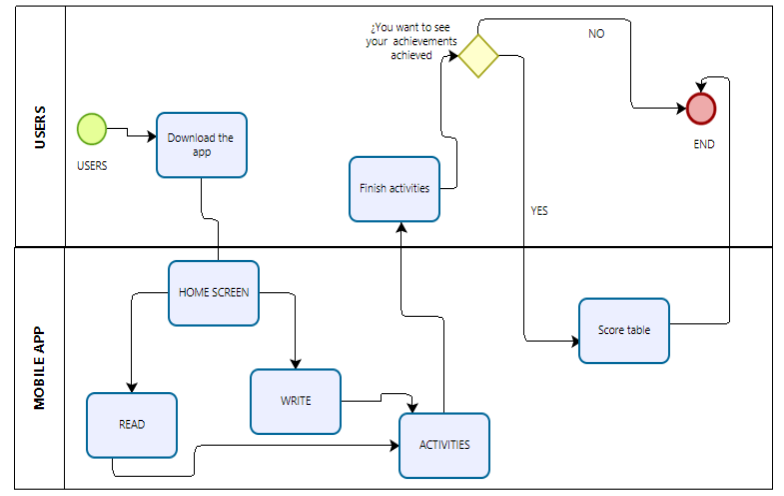

Fig.3 Mobile app usage Flow chart

\section{F. Technological tools}

1) Android application: The tools for the development of the mobile application are programs, frameworks, environments, libraries, etc. Therefore, these tools are very useful when developing the mobile application, as they will make it more secure, agile, simple, etc.

a) Application Framework: It is a set of development tools, where all applications use the same APIs and the same Framework.

b) Libraries: Libraries have been created using $\mathrm{C} / \mathrm{C}++$ since they are the pillars that constitute Android.

c) Android Studio: It is an integrated development environment (IDE), based on Intellij IDEA of the company JetBrains.

2) Hybrid Application: To develop a hybrid application it has been found that the appropriate one would be Xamarin, since it offers us to generate versions on Android, IOS and Windows Phone, etc. In addition, it offers us continuous integration, it is very easy to install and easy to learn, in Fig. 4 we can see its application architecture in Xamarin.

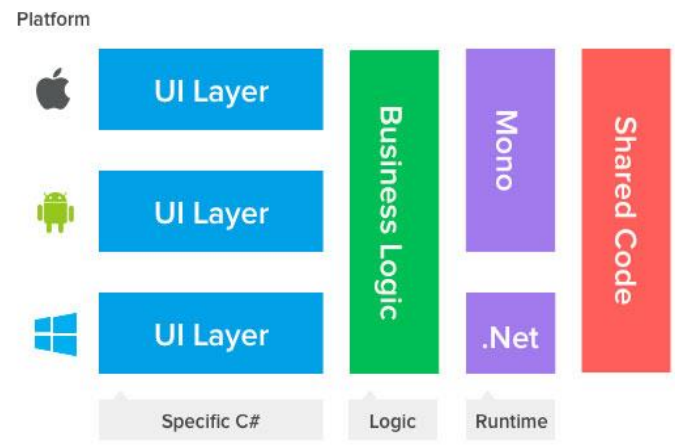

Fig.4 Application architecture in Xamarin [10].

\section{G. Define}

According to the plan designed by the Ministry of Education for an illiterate person to learn to read and write, it is by attending a literacy program where participants acquire skills to read and write in their mother tongue and in Spanish, in this way, they will be affirming their identity and revaluing their language and culture.

Also, it is known that the classes offered by this literacy program last 3 months and 1 additional month of reinforcement.

The educational forum specialist Madeleine Zúñiga, points out that it is important to use various methods for literacy, where you have to put in constant practice what you have learned.

In the same way, it points out that illiteracy has deep socioeconomic roots [11].

\section{H.Devise}

It seeks to develop a mobile application so that illiterate children and adults can learn to read and write through it, where appropriate teaching methods will be used and activities will be carried out by levels, which will consist of learning in the most basic way and little little by little, the complexity increases.

On the other hand, we know that the use of technology in education brings satisfactory results, since it turns out to be very innovative [12].

\section{Prototype}

To develop the research work, the following programs were used, since they were the most appropriate to carry out the survey and design the prototype.

1) Google Forms: This tool allows you to carry out surveys, collect data, perform evaluations, since it can be connected to a spreadsheet [13]. In this way, it will allow us to know the statistical data of our survey carried out on a group of people and to know how we can develop the prototyping, knowing the causes, consequences of illiteracy, the implementation of the prototype according to the characteristics provided by the respondents.

2) Moqups application: It is a very easy-to-use tool that allows designing user interfaces for web pages and mobile applications, making it look real and allowing the developer to implement all their creativity while using it [14].

\section{J. Evaluate}

It is known that children from a young age already use technologies, whether through tablets, cell phones or laptops. 




International Journal of Emerging Technology and Advanced Engineering Website: www.ijetae.com (E-ISSN 2250-2459, Scopus Indexed, ISO 9001:2008 Certified Journal, Volume 12, Issue 02, February 2022)

For this reason, one of the main advantages of the use of technology in education is that children as adults can access a greater amount of teaching materials such as electronic books, using technology favors autonomous learning, since they only need access to educational apps and games to enhance your learning.

In the same way, the use of technology in class generates a great advantage, since the students will pay more attention and it will make the class more fun and entertaining [15].

\section{RESULTS AND DISCUSSIONS}

\section{A. About The Survey}

A survey was conducted with 30 parents in order to find out their opinion on what were the causes and consequences of illiteracy in Peru. In the same way, they wanted to know how they would like the mobile application to be implemented.

Fig. 5 shows the results obtained on the question: What do you think is the main cause of illiteracy in our country?, where $65.5 \%$ indicated the need to work at an early age, while $24.1 \%$ the lack of schools and teachers, also $10.3 \%$ indicated that it was the lack of interest of those affected by wanting to learn.

They were also asked, what was the main consequence of illiteracy? where the majority indicated that they did not know what their rights are and that means that they could have labor exploitation, also the lack of opportunities, since as we know to achieve a job with benefits According to the law, it is necessary to have a complete secondary minimum requirement.

What do you think is the main cause of illiteracy in our country?

29 r

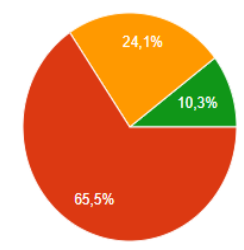

- The need to work at an early age.

- lack of schools and teachers

- The lack of interest of those affected by warting to learn

Fig.5 What do you think is the main cause of illiteracy in our country?

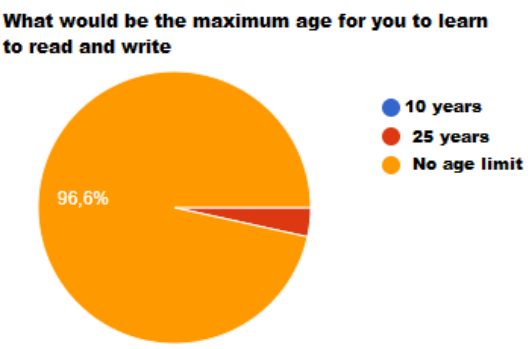

Fig.6 What would be the máximum age for you to learn $t$ oread and write

In Fig. 6 we can see the results of the question What age is the maximum age to learn to read and write? where $96.6 \%$ indicated that there is no age limit to learn, while $4.4 \%$ indicated the 25 years old.

In the same way, Fig. 7 shows the results of the question Do you think that you can learn to read and write through a mobile application? where $51.7 \%$ indicated that perhaps it could be learned, while $48.3 \%$ said that it can be learned.

Similarly, the last 2 questions were asked, which consisted of the structure and objective of the mobile application, the results are shown in Table I and Table II.

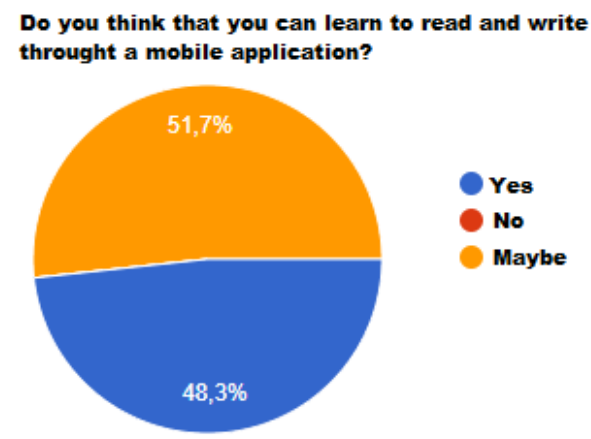

Fig.7 Do you think that you can learn t oread and write throught a mobile Application?

TABLE I

Objectives of the Application

\begin{tabular}{|c|c|}
\hline \multicolumn{2}{|c|}{$\begin{array}{c}\text { What should the mobile Application have to achieve with the } \\
\text { goal(learn t oread and write? }\end{array}$} \\
\hline $\begin{array}{c}\text { Question } \\
\text { It should be base don teaching methods of } \\
\text { adequate literacy }\end{array}$ & $69 \%$ \\
\hline $\begin{array}{c}\text { It must be creative and innovative } \\
\text { It should be simple and easy to use }\end{array}$ & $41,4 \%$ \\
\hline Free and easy to use & $37,9 \%$ \\
\hline
\end{tabular}






International Journal of Emerging Technology and Advanced Engineering Website: www.ijetae.com (E-ISSN 2250-2459, Scopus Indexed, ISO 9001:2008 Certified Journal, Volume 12, Issue 02, February 2022)

TABLE II

Structure of the mobile application

\begin{tabular}{|c|c|}
\hline How should the mobile Application be structured? \\
\hline Question & Outcome \\
\hline Educational games & $58,6 \%$ \\
\hline Congratulations messages & $37,9 \%$ \\
\hline Educational activities & $72,4 \%$ \\
\hline Scoring table & $34,5 \%$ \\
\hline Educational images and videos & $17,2 \%$ \\
\hline Downloadable tabs & $17,2 \%$ \\
\hline Motivating messages & $37,9 \%$ \\
\hline
\end{tabular}

\section{B. About The Prototypes}

The prototypes of the mobile application were developed with the Moqups program.

Likewise, the design was implemented with the needs that were deemed convenient for prototyping.

In Fig. 8 you can see what would be the main screen of the mobile application, as it is known it is aimed at children and adults who cannot read or write. Therefore, we have 2 options, which are reading and writing, which for easy handling and access is represented by images, by clicking on the option of your choice, it will present the activities for the selected option.

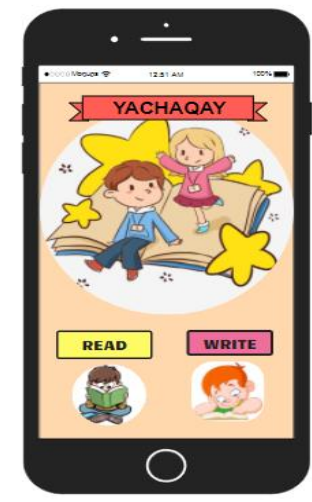

Fig.8 Home "YACHAQAY"

In Fig. 9 the option to read is observed, which shows the 3 activities that are made up of the educational methods selected for better performance, which are the syllabic method and the alphabetical method. In this way, the activity that is related to vowels is observed, the user by selecting the images that appear on the screen will be able to hear the name of each image, which will help them to repeat to be able to read and see how it is written.
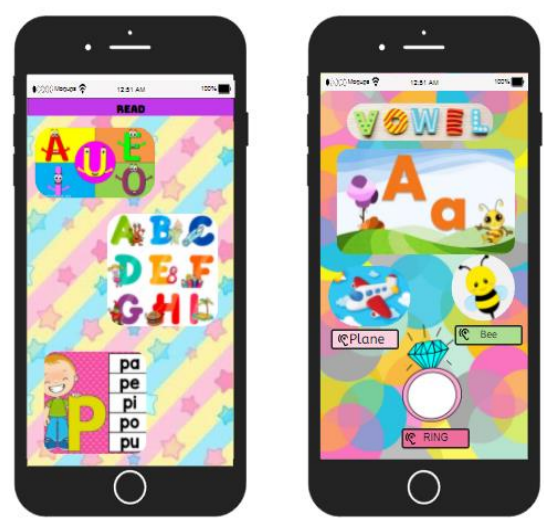

Fig.9 Read option screen

In Fig. 10 there are 2 activities, the first one is that the user can complete the missing syllable, for that there is an icon that will reproduce the sound of the word and according to what is heard, they can complete it, the second activity is an image and below her name is separated by syllables, it also has an icon that will reproduce how the word sounds. Therefore, the user will be able to observe how the provided image is written.

Likewise, in Fig. 11 you have the option to write, which has 2 options, which is to learn to write in upper- and lower-case letters, by selecting the desired option you will be able to view activities as can be seen in Fig. 12, where the user will have to look for the word provided on the keyboard and have to trace the vowel or letter provided, this will help them to be able to have a command of the hand so that they can learn to write.

Finally, the user, once completed with the activities provided, the application will show him congratulations for having completed the activities and will ask him, if he wants to see his achievements from the first day, this can be seen in Fig. 13.

\section{About the methodology}

\section{1) Advantage}

One of the main advantages of using a hybrid methodology is that we can join the best stages of each one and show a concrete result of what you hope to achieve. That in this way, it was decided to implement a hybrid methodology since it allowed us to look for the causes of the problem and to be able to find a solution through the user's requirements and teaching methods in order to develop a prototype of a mobile application. 


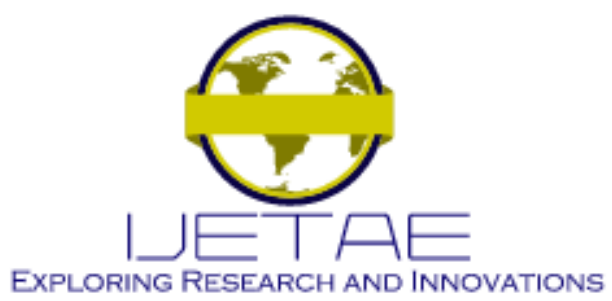

International Journal of Emerging Technology and Advanced Engineering Website: www.ijetae.com (E-ISSN 2250-2459, Scopus Indexed, ISO 9001:2008 Certified Journal, Volume 12, Issue 02, February 2022)

\section{2) Disadvantages}

The main disadvantage of using a hybrid methodology is that they have not yet been tested in large information systems and are new to the market.

\section{3) Comparasion}

The design of this mobile prototype is very accessible to users, since it has 2 important objectives, which is to learn to read and write, which will be represented by 2 images that refer to each activity. Likewise, the activities provided for the application were taken from appropriate teaching methods in order to achieve (learn to read and write). In this way, it began with easy activities for better performance, when completing the activities each user will be able to see how they have been improving every day.

The recommendation is that they can use more teaching methods for easy learning and can implement an emerging technology such as voice assistants so that users can find the right answers on how to use the mobile application.

In accordance with other research works, the author [16] included reading comprehension exercises, which for a person who is just learning to read and write will not be easy to solve, while in our mobile application prototype we have started with basic activities so that users can learn from scratch with the appropriate teaching methods to learn to read and write.

Likewise, the author [17] provides teaching methods for children with learning difficulties where parents play an important role in being aware of the development of the activities provided in the application, but what would happen if an adult or child does not have someone that can guide you to use the application. That is why you should think about developing an application that is easy to use.
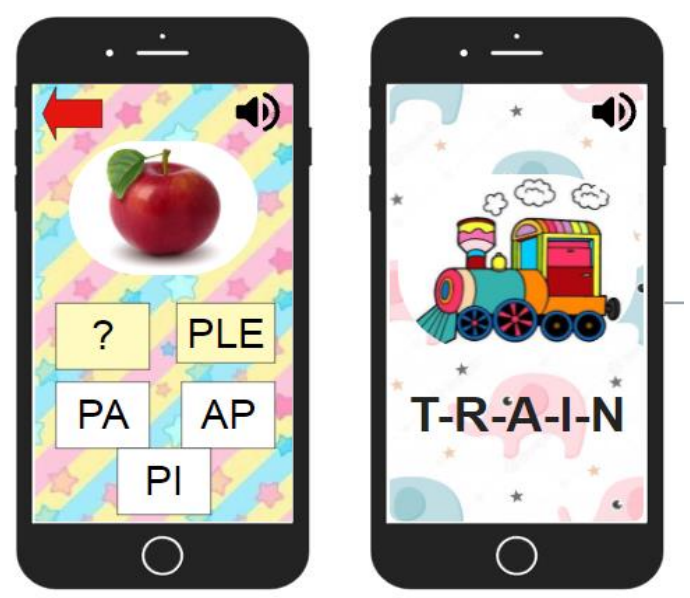

Fig.10 Reading activities



Fig.11 Write option screen
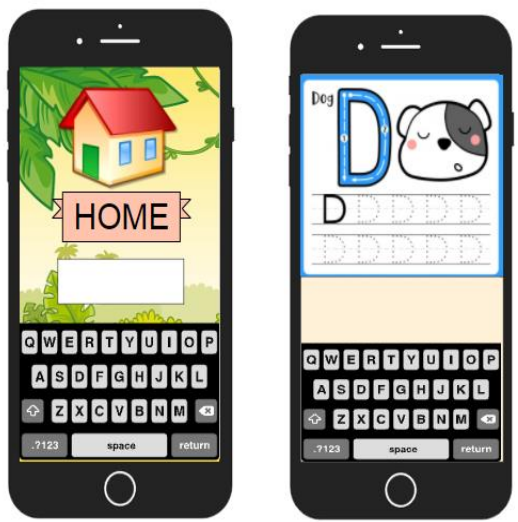

Fig.12. Writing activities
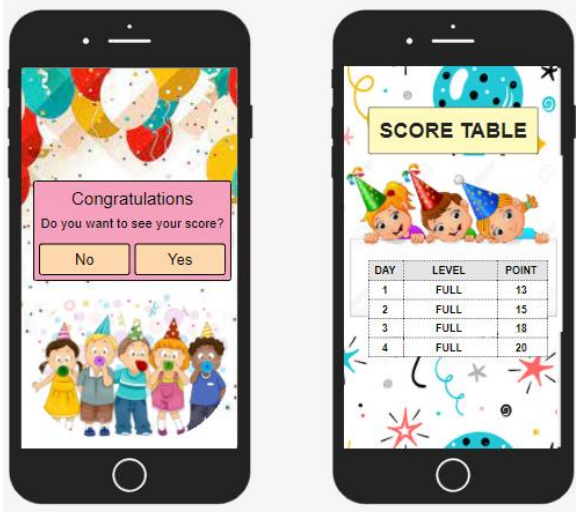

Fig.13 score Table 




International Journal of Emerging Technology and Advanced Engineering Website: www.ijetae.com (E-ISSN 2250-2459, Scopus Indexed, ISO 9001:2008 Certified Journal, Volume 12, Issue 02, February 2022)

\section{CONCLUSIONS}

Through this research work, it was possible to design the prototype of a mobile application through the Mockups tool that shows what the mobile application will have so that children and adults who do not know how to read and write learn through this application, since it is based on appropriate learning methods such as the alphabetic method and the syllabic method. In this way, it is expected to reduce illiteracy in rural areas of our Peru.

Likewise, the methodology used is a hybrid methodology, that is why the prototypes were designed to appear real, the activities provided through this prototype were developed so that users can learn in an easy and simple way.

Finally, it is recommended as future work that technological tools continue to be implemented to reduce illiteracy worldwide so that everyone can access quality education.

\section{REFERENCES}

[1] R. (2019, 29 noviembre). Cinco retos que enfrenta la educación en el Perú. RPP. https://rpp.pe/campanas/contenido-patrocinado/5-retosque-enfrenta-la-educacion-en-el-peru-noticia-1156259?ref=rpp (references)

[2] BBC News Mundo. (2019, 4 diciembre). Qué países tienen la mejor educación del mundo (y qué lugar ocupa América Latina en la clasificación). El Comercio Perú https://elcomercio.pe/mundo/actualidad/pruebas-pisa-que-paisestienen-la-mejor-educacion-del-mundo-y-que-lugar-ocupa-americalatina-en-la-clasificacion-noticia/?ref=ecr

[3] (S/f). Gob.pe. Recuperado el 13 de septiembre de 2021, de http://www.minedu.gob.pe/files/536_201110261539.pdf

[4] Gámez, F. I. L., Rodríguez, M. R., \& Torres, L. E. S. (2018). Uso y aplicación de las TIC en el proceso de enseñanzaaprendizaje. Revista Científica de FAREM-Estelí, (25), 16-30.
[5] Jiménez-García, M., \& Martínez-Ortega, M. Á. (2017). El uso de una aplicación móvil en la enseñanza de la lectura. Información tecnológica, 28(1), 151-160.

[6] Jiménez-García, M., \& Martínez-Ortega, M. Á. (2017). El uso de una aplicación móvil en la enseñanza de la lectura. Información tecnológica, 28(1), 151-160.

[7] Quispe, A., Bernal, C., \& Salazar, G. (2017). Uso de aplicaciones móviles educativas para niños con dificultades de aprendizaje. Campus, 24(22), 17.

[8] E. (2021b, septiembre 9). Método alfabético de enseñanza de la lectoescritura. Portal Educativo de apoyo a Padres, Maestros y Niños en las Tareas Escolares. https://www.educapeques.com/escuela-depadres/metodo-alfabetico.html

[9] Ramírez, J. A. (2019). Los principios de la conciencia fonológica en el desarrollo de la lectoescritura inicial. Revista de lenguas modernas, (30).

[10] uTech Academy. (2019, 28 febrero). Cómo desarrollar una aplicación móvil híbrida. https://utech.academy/blog/comodesarrollar-una-aplicacion-movil-hibrida/

[11] A. (2011, 15 septiembre). Madeleine Zúñiga: La educación no atendió a zonas rurales. CPDE. http://cpde.org.pe/madeleine-zunigala-educacion-no-atendio-a-zonas-rurales/

[12] García-Rodríguez, A., \& Gómez-Díaz, R. (2017). Lectura digital infantil: dispositivos, aplicaciones y contenidos. Editorial UOC.

[13] Alpízar, A. B., \& Prado, G. D. C. (2016, September). Uso de los formularios de Google para recopilación de información estadística y su posterior análisis con Geogebra. In V Encuentro sobre Didáctica del Estadística, la Probabilidad y el Análisis de Datos.

[14] NAVA, M. R. Z. (2017). Análisis de herramientas para el diseño de

[15] Gómez-Díaz, R., García Rodríguez, A., \& Cordón-García, J. A. (2015). APPrender a leer y escribir: aplicaciones para el aprendizaje de la lectoescritura.

[16] Jiménez-García, M., \& Martínez-Ortega, M. Á. (2017). El uso de una aplicación móvil en la enseñanza de la lectura. Información tecnológica, 28(1), 151-160.

[17] Quispe, A., Bernal, C., \& Salazar, G. (2017). Uso de aplicaciones móviles educativas para niños con dificultades de aprendizaje. Campus, 24(22), 17. 